\title{
Fluctuating Pupil-sparing Oculomotor Nerve Palsy with Intracranial Spontaneous Dissecting Aneurysm
}

Intrakraniyal Spontan Dissekan Anevrizmaya Bağlı Fluktuasyon Gösteren Okulomotor Sinir Felci

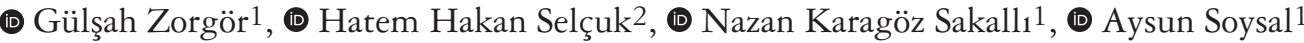 \\ 1 University of Health Sciences Turkey, Basaksehir Cam and Sakura City Hospital, Clinic of Neurology, Istanbul, Turkey \\ 2University of Health Sciences Turkey, Istanbul Bakirkoy Dr. Sadi Konuk Training and Research Hospital, Clinic of Radiology, \\ Istanbul, Turkey
}

\begin{abstract}
Oculomotor nerve palsy secondary to a compressive lesion is typically presented with clinical findings like anisocoria and ptosis. Seldom does its atypical presentation mimic the features of other neurological diseases. Hence, considering the underlying cause is vital, as it may rarely be the first sign of a ruptured or non-ruptured aneurysm, even if the absence of pupil involvement does not suggest such compressive causes. Herein, we reported the case of a patient who presented with fluctuating ptosis and diplopia secondary to spontaneous dissecting aneurysm of the internal carotid artery.
\end{abstract}

Keywords: Oculomotor nerve palsy, dissecting aneurysm, cerebral aneurysm, internal carotid artery

$\ddot{\mathbf{O z}}$

Kompresyona bağlı okulomotor sinir felci anizokori ve pitoz gibi tipik klinik bulgular ile prezente olur. Nadiren birçok nörolojik tabloyu taklit eder şekilde atipik prezentasyon gösterebilir. Özellikle pupil tutulumu eşlik etmediği durumlarda okulomotor sinire bası yapan kompresif sebeplerden uzaklaşılsa da nadiren altta yatan sebebin rüptüre ya da rüptüre olmamış bir anevrizmanın ilk bulgusu olabileceğini göz önünde bulundurmak hayati önem taşır. Bu yazıda internal karotid arterdeki spontan dissekan anevrizmaya sekonder fluktuasyon gösteren pitoz ve diplopi ile prezente olan bir olgudan bahsedeceğiz.

Anahtar Kelimeler: Okulomotor sinir palsi, dissekan anevrizma, serebral anevrizma, internal karotid arter

\section{Introduction}

Oculomotor nerve palsy may develop due to any lesion during its course from the oculomotor nucleus to the orbit (1). The assessment of pupil involvement (pupil-involving or pupil-sparing) is vital for differential diagnosis (2). Oculomotor nerve palsy with pupil involvement often occurs secondary to a compressive lesion, such as an aneurysm (3). An aneurysm that causes oculomotor nerve palsy is usually located at the junction of the internal carotid and posterior communicating (PCom) arteries (4).

This report describes the case of a 47-year-old female patient who had a rare atypical presentation of the third nerve palsy, with pupil-sparing and fluctuating symptoms, which were secondary to a spontaneous dissecting aneurysm of the internal carotid artery (ICA).

\section{Case Report}

A 47-year-old female patient, with no known chronic medical illness, was admitted to our hospital with a 1-year history of right upper lid ptosis and a 3-day history of intermittent diplopia without any complaints. The ptosis and diplopia that worsened upon waking up were resolved during the day. Neuro-ophthalmic examination revealed that the right eye was depressed and abducted in the primary position with ipsilateral partial ptosis (Figure 1A). The patient demonstrated painless, mild restrictions during the

Address for Correspondence/Yazışma Adresi: Gülşah Zorgör MD, University of Health Sciences Turkey, Basaksehir Cam and Sakura City Hospital, Clinic of Neurology, Istanbul, Turkey

Phone: +90 5544469876 E-mail: gulsah.zrgr@gmail.com ORCID: orcid.org/0000-0003-2071-5276

Received/Geliş Tarihi: 16.11.2020 Accepted/Kabul Tarihi: 23.04.2021

${ }^{\circ}$ Copyright 2021 by Turkish Neurological Society

Turkish Journal of Neurology published by Galenos Publishing House. 
right eye elevation and adduction. The pupils were equal in size and reactive to light. No relative afferent pupillary defect was noted. The confrontation visual field test results were normal. The patient denied the occurrence of any present or previous headaches. No ptosis was observed the next day. The eyes were aligned in the primary position, with no other ocular movement abnormality, except a slightly limited elevation of the right eye. The neuro-ophthalmic examinations remained the same for the subsequent days. The initial blood investigations were normal. The systolic and diastolic pressure values were higher than 150/90 $\mathrm{mmHg}$ in the morning, whereas systolic and diastolic pressures were $110-120 \mathrm{mmHg}$ and under $80 \mathrm{mmHg}$, respectively, during the day. Chest radiography, cranial computerized tomography, and magnetic resonance imaging results were normal. Cranial magnetic resonance angiography (Figure $2 \mathrm{~A}$ ) revealed a small aneurysm in the cavernous segment of the right ICA. Cerebral digital subtraction angiography also showed a dissecting aneurysm in the cavernous segment of the right ICA (Figure 2B). The patient underwent endovascular treatment with a flow diverter stent. Ptosis and the restriction of upgaze in the right eye improved at discharge and did not recur (Figure 1B). Follow-up cerebral angiogram that was performed three months after the endovascular treatment showed complete aneurysm occlusion (Figure 2C).

\section{Discussion}

Our patient's clinical presentation of a third nerve palsy secondary to a compressive lesion had many atypical features. First, the pupils were not affected. Unlike cranial third nerve dysfunction that develops secondary to microvascular ischemia, in which the pupils remain intact, oculomotor nerve palsy due to an aneurysm is characterized by pupil involvement first, followed by ptosis and extraocular muscle paresis. This phenomenon is explained by the impaired vascular supply of the third nerve that affects the central fibers deep within the nerve, whereas the peripherally located parasympathetic fibers are spared in ischemic palsy (3). However, multiple reports $(4,5,6)$ have revealed cases of oculomotor nerve compression in which the pupils remained intact. The accepted mechanism of mydriasis is compression of the aneurysm superomedially on the pupillomotor fibers due to the course over the dorsomedial surface of the third nerve in the ICA-PCom aneurysm $(3,7)$. However, the aneurysm present in our patient was on the inferior side of the oculomotor nerve. Therefore, pupil-sparing should not rule out compression.

Another atypical feature of our patient was the absence of the frequently expected headache or periorbital pain in the nerve palsy due to an aneurysm. The oculomotor nerve does not have painsensitive fibers, thus, pain is considered to be due to the distention of the arterial wall of the aneurysm (6). Thus, the lack of pain in oculomotor nerve palsy does not exclude the possibility of an underlying intracranial aneurysm.

Cases with fluctuating diplopia and ptosis, as in our case, have been rarely reported $(8,9,10)$. These intermittent symptoms, at first, could suggest a neuromuscular problem. However, the worsening of symptoms on waking led us to believe that was not the case. A possible mechanism of fluctuation is the pulsating effect of the aneurysm on the oculomotor nerve (11). Diplopia is considered to occur in the morning hours due to the increased pulsation effect of the aneurysm on the nerve because of elevated
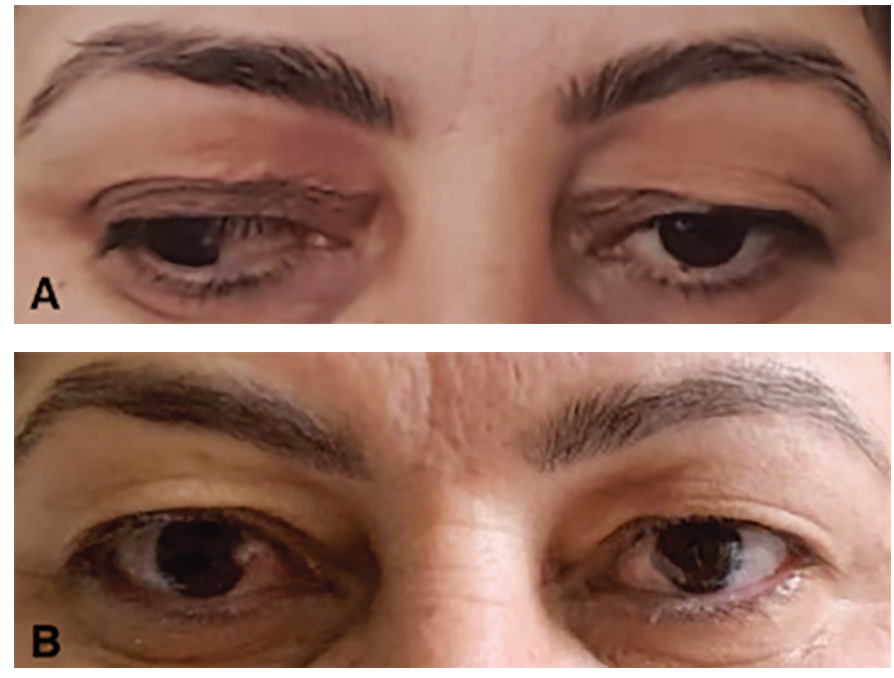

Figure 1. A) Right-sided depression and abduction in the primary position of the pupil and ipsilateral partial ptosis

B) At discharge, the limitations of the ocular movements were improved
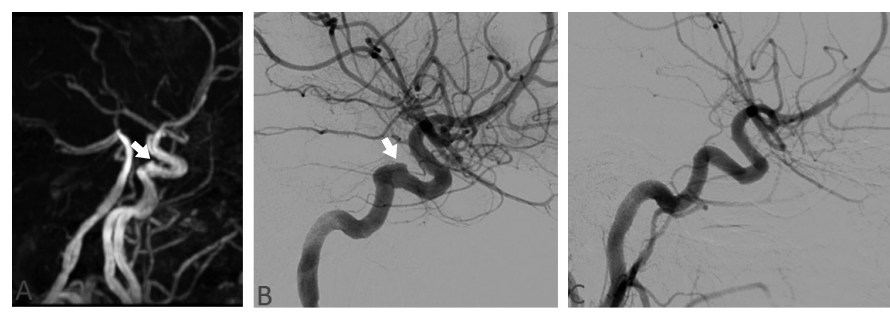

Figure 2. A) Cranial magnetic resonance angiography in lateral view shows an aneurysm (arrow) in the cavernous segment of the right internal carotid artery (ICA). B) Right carotid artery angiogram in lateral view shows a dissecting aneurysm (arrow) in the cavernous segment of the ICA. C) Follow-up cerebral digital subtraction angiography 3 months after flow diversion therapy; right ICA lateral view shows the total occlusion of the aneurysm

blood pressure levels and improves during the day when the blood pressure levels returns to normal.

In our patient, the cause of the compression was a non-traumatic dissecting aneurysm of the cavernous segment of the ICA, which is relatively uncommon. The presence of fluctuating diplopia, ptosis, and pupil-sparing third nerve palsy is not sufficient to rule out a compressive etiology. Moreover, the lack of pain should not exclude the possibility of nerve compression. The underlying etiology can be life threatening, thus, the possibility of an aneurysm must be excluded first, regardless of how atypical the symptoms are.

\section{Ethics}

Informed Consent: Written consent was obtained from the patient.

Peer-review: Externally and internally peer-reviewed.

\section{Authorship Contributions}

Surgical and Medical Practices: G.Z., H.H.S., Concept: G.Z., H.H.S., N.K.S., A.S., Design: G.Z., H.H.S., N.K.S., A.S., Data 
Collection or Processing: G.Z., H.H.S., N.K.S., A.S., Analysis or Interpretation: G.Z., H.H.S., N.K.S., A.S., Literature Search: G.Z., H.H.S., N.K.S., A.S., Writing: G.Z.

Conflict of Interest: The authors have not declared any conflict of interest related to this article.

Financial Disclosure: No financial support was received from any institution or person for our study.

\section{References}

1. Woodruff MM, Edlow JA. Evaluation of third nerve palsy in the emergency department. J Emerg Med 2008;35:239-246.

2. Kung NH, Van Stavern GP. Isolated ocular motor nerve palsies. Semin Neurol 2015;35:539-548.

3. Joshi S, Tee WWH, Franconi C, Prentice D. Transient oculomotor nerve palsy due to non-aneurysmal neurovascular compression. J Clin Neurosci 2017;45:136-137.

4. Srinivasan A, Dhandapani S, Kumar A. Pupil sparing oculomotor nerve paresis after anterior communicating artery aneurysm rupture: false localizing sign or acute microvascular ischemia? Surg Neurol Int 2015;6:46.
5. O'Connor PS, Tredici TJ, Green RP. Pupil-sparing third nerve palsies caused by aneurysm. Am J Ophthalmol 1983;95:395-397.

6. Ajtai B, Fine EJ, Lincoff N. Pupil-sparing, painless compression of the oculomotor nerve by expanding basilar artery aneurysm: a case of ocular pseudomyasthenia. Arch Neurol 2004;61:1448-1450.

7. Kim DJ, Kim DI, Lee SK, et al. Unruptured aneurysms with cranial nerve symptoms: efficacy of endosaccular Guglielmi detachable coil treatment. Korean J Radiol 2003;4:141-145.

8. Birchall D, Khangure MS, McAuliffe W. Resolution of third nerve paresis after endovascular management of aneurysms of the posterior communicating artery. AJNR Am J Neuroradiol 1999;20:411-413.

9. Dayan MR, Elston JS. Fluctuating oculomotor hyperfunction and hypofunction caused by aneurysmal compression of the third cranial nerve. Br J Ophthalmol 1999;83:1204.

10. Attia S, Zaouali S, Chourabi C, et al. Fluctuating ptosis, diplopia, and normal pupils with intracavernous aneurysm. J Neuroophthalmol 2007;27:83-84.

11. Giombini S, Ferraresi S, Pluchino F. Reversal of oculomotor disorders after intracranial aneurysm surgery. Acta Neurochir (Wien) 1991;112:19-24. 